\title{
Törött ortopédiai implantátumok károsodásanalízise
}

\section{Failure analysis of broken orthopedic implants}

\author{
Simon Ágota, ${ }^{1}$ Asztalos Lilla ${ }^{2}$ \\ Budapesti Müszaki és Gazdaságtudományi Egyetem, Anyagtudomány és Technológiai Tanszék, Budapest, \\ Magyarország \\ 1 simon_agota@yahoo.com \\ 2 lilla@eik.bme.hu
}

\begin{abstract}
Joint implants and fixings are subject to many stresses throughout their life cycle. Despite careful design, material selection, manufacturing technology and proper surgical technology, implant damage and, in extreme cases, fracture can occur. Investigation of injuries is important from the perspective of the patient, the care provider and the manufacturer, among other things, by exploring the cause of the fracture to prevent similar cases. In the present study we performed failure analysis of a hip implant and a bone fixation plate. Fracture surfaces, material composition, material structure and hardness were also investigated. Based on the work done, we determined what might have led to the fracture in both cases.
\end{abstract}

Keywords: hip implant, bone fixation, fracture, damage analysis.

\section{Összefoglalás}

Az ízületi implantátumokat és rögzítőket életciklusuk alatt számos igénybevétel éri. A körültekintő tervezés, anyagválasztás, gyártástechnológia és megfelelő műtéti technológia ellenére is bekövetkezhet az implantátum károsodása, szélsőséges esetben pedig akár a törése is. A káresetek kivizsgálása a beteg, a kezelést végző intézmény és a gyártó szemszögéből is fontos, többek között azáltal, hogy a törés indokának feltárásával megelőzhetők a hasonló esetek. Jelen kutatómunkában egy csípőimplantátum és egy csontrögzítő lemez károsodásanalízisét végeztük el. Vizsgáltuk a töretfelületeket, az anyagösszetételt, az anyagszerkezetet és a keménységet is. Az elvégzett munka alapján meghatároztuk, hogy mi vezethetett mindkét esetben a töréshez.

Kulcsszavak: csípőimplantátum, csontrögzítő, törés, károsodásanalízis.

\section{Bevezetés}

Napjaink gyakori betegségeként tarthatóak számon az ízületeket érintő megbetegedések, ilyenek a kor előrehaladtával járó csontsürűség-csökkenés és a kopásos betegség. A csontsűrűség-csökkenés következménye lehet a csont törése, a kopásos betegség a test vertikális helyzetéből adódóan a csigolyákat és a csípőízületeket érinti elsősorban. A combcsont feje és a vápa belső felszíne maga az ízületi porc, amely lehetővé teszi, hogy a két csont felszíne egymáson sérülésmentesen csússzon. Az ízületet izmok és inak tartják stabilan [1, 2].

Az előrehaladott állapotú csípőízület-betegsé- gek leghatékonyabb kezelési módja a teljes ízületi pótlás csípőimplantátummal. Ezek az implantátumok készülhetnek különböző anyagokból, és a beültetésük módja is eltérő lehet. A kor és a beteg életvitele fogja leginkább meghatározni azt, hogy az orvos milyen technikát és implantátumot választ a beteg számára [1, 2].

Abban az esetben, ha combcsonttörést szenvedett el, más eszköz szükséges a csont és az ízület helyreállításához. Ilyenkor csontrögzítő lemezt alkalmaznak. A lemezt csavarok segítségével rögzítik a törött csontrészletekhez. Ebben az esetben a csavarozás módja lehet kompressziós, illetve semleges [3]. 


\subsection{Az implantátumok károsodása}

$\mathrm{Az}$ ortopédiai implantátumok várható élettartama akár 30 év is lehet, viszont a csípőimplantátumok esetében a vápabetét és a moduláris fej kopása, valamint az implantátum kilazulásának megelőzése vagy kezelése miatt ennél rövidebb idő után, 10-15 évente az implantátumok cseréje vagy más néven revíziója szükséges [4-7].

Az implantátumok a beültetést követően különféle hatásoknak vannak kitéve, mint például a mechanikai igénybevétel, súrlódás, de akár a mütéti beavatkozás során is lehetnek olyan tényezők, amelyek az implantátum élettartamát csökkentik. Ezekben az esetekben akár már néhány éven belül a páciens panaszokkal térhet vissza a kezelőorvoshoz. A csontsürüség csökkenése is tényezőként hathat a protézis károsodására, mivel a csont szerkezete már nem képes az implantátum stabilitását megtartani [5].

A beültetés sikerességét befolyásolja a mütéti technika, hogy megfelelő szögben és mértékben történt-e a rögzítés. Magán az implantátumon és a mütéti beavatkozáson túl a beteg is fontos szerepet kap az implantátum állapotának a megőrzésében, be kell tartania a gyártó és az orvos által előírtakat [4, 6]. Vannak esetek, amikor a beteget ért baleset áll a károsodás hátterében, de akár a hosszabb ideig tartó, nagyobb mértékű terhelés is lehet kiváltó ok. Ilyen eset például az ellentétes csípő fájdalma, az ebből következő helytelen járásminta [7, 8].

A károsodási típusok általában a törés, kopás, lazulás és a ficam is [4-8]. Ezek közül a legsúlyosabb eset, amely a beteg életminőségét a leginkább befolyásolja, a törés. Annak kiderítésére, hogy mi állt a törés hátterében, a károsodott mintákon károsodásanalízist kell elvégezni.

\subsection{Törött implantátumok károsodásanalízise}

Mivel a károsodás a beteg életminőségének jelentős romlásával járhat, minden esetet érdemes kivizsgálni. A szakirodalomban is számos cikk közöl esettanulmányokat [4-8], de a csípőimplantátumok igénybevételeinek végeselemes modellezésével [9] is igyekeznek a témát minél pontosabban körbejárni. A legtöbb cikk az orvosi oldalt helyezi előtérbe, viszont a károsodott fém metallográfiai és korróziós tulajdonságait tárgyaló cikkeket is lehet találni [10, 11].

A BME Anyagtudomány és Technológia Tanszékén az elmúlt években több törött csípőimplantátum káresetének kivizsgálását végezték el. Jelen kutatásunk alapjául is ezek a mérések szolgáltak, és a szakirodalomban talált módszereket alkalmazva állítottunk össze egy vizsgálati protokollt a káresetek feltárására.

\section{Módszerek}

Kutatásunk célja két törött implantátum károsodáselemzésének elvégzése, a károsodás okának feltárása. Az egyik vizsgált implantátum egy csípőprotézis (1. ábra), amely a szári részén tört el, a másik eszköz pedig egy csontrögzítő lemez (2. ábra). Ez utóbbi esetében a rögzítőcsavarok is rendelkezésre álltak, amelyeken ugyan törésnyomokat makroszkopikusan nem detektáltunk, de a káreset teljes körű kiértékelése érdekében ezeket is megvizsgáltuk.

\subsection{Minta-előkészítés}

A károsodott implantátumokról a beérkezési állapotában makroszkopikus felvételeket készítettünk, ezt követte egy ultrahangos tisztítás. Ahhoz, hogy az implantátum töretfelületeit megfelelően tudjuk kivizsgálni, az implantátumokat feldaraboltuk, a törésvonaltól 10 mm távolságban. Hogy az anyag keménységét és szövetszerkezetét is vizsgálni tudjuk, a törésvonallal párhuzamosan további szeleteket vágtunk ki (3. ábra).

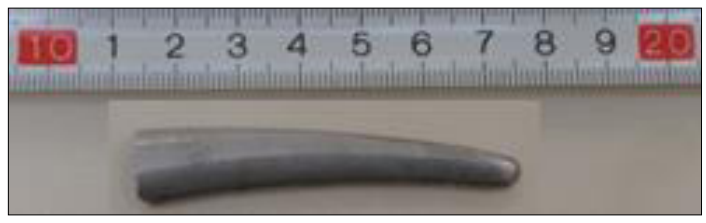

1. ábra. A vizsgált csípőimplantátum disztális vége

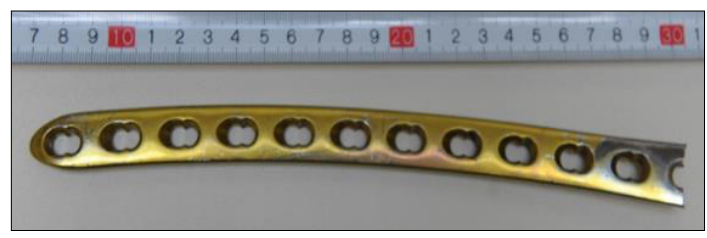

2. ábra. A vizsgált csontrögzítő lemez disztális vége

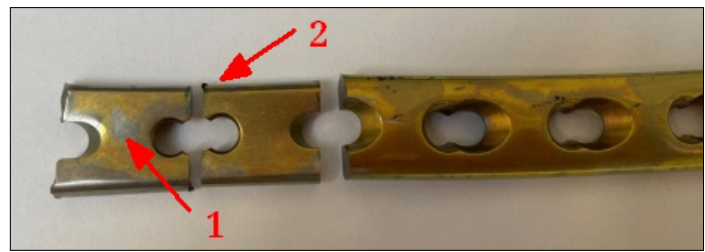

3. ábra. A csontrögzítő lemez disztális része a darabolást követően. A töretfelületet tartalmazó szelet 1-es, a metallográfiai és keménységmérési vizsgálatokhoz használt darab 2-es számmal jelölve 


\subsection{Fraktográfia}

Fraktográfia alatt a töretfelületek elemzését értjük. Az eltávolított töretfelületekről sztereomikroszkóppal (Olympus SZX16) készítettünk felvételeket különböző nagyításokban. A kis nagyítás és az optikai mikroszkópokra jellemző kis mélységélesség miatt ezekkel a vizsgálatokkal a törés pontos oka nem megállapítható.

A töretfelületekről ezután pásztázó elektronmikroszkóp (Zeiss EVO MA 10) segítségével készítettünk nagyobb nagyítású felvételeket. A töretfelületek peremét végigpásztázva, a felületről induló repedésvonalakat, valamint anyagfolytonossági hiányokat kerestünk, amelyek szerepet játszhattak a károsodásban.

\subsection{Metallográfia}

A metallográfiai vizsgálatok célja az implantátumanyag szövetszerkezetének elemzése. A mérések elvégzéséhez a minta-előkészítés során ismertetett módon eltávolított darabokat beágyaztuk, majd csiszoltuk és políroztuk. A polírozott felületekről fémmikroszkóppal készítettünk felvételeket, amelyen a jellegzetes mikroszerkezeti sajátosságok (kiválások) láthatók. A polírozott minták maratásával a szövetszerkezet is láthatóvá válik. A lemez és a rögzítőcsavar esetében Kroll-féle reagenst ( $92 \mathrm{~mL} \mathrm{H}_{2} \mathrm{O}, 6 \mathrm{~mL} \mathrm{HNO}_{3}, 2 \mathrm{~mL}$ HF), a csípőimplantátum esetében pedig sósavat használtunk. A mikroszkópos képek segítségével megállapítható az átlagos szemcseméret és a szemcseszerkezet homogenitása is.

\subsection{Anyagösszetétel-elemzés}

Mind a töretfelületen, mind az elkészített csiszolatokon anyagösszetételi elemzést végeztünk energiadiszperzív röntgenspektrometriával (Edax Metek Elect Plus készülékkel). Az anyagöszszetétel-vizsgálatokkal azonosítani tudjuk az implantátumok anyagát, valamint összehasonlíthatjuk az értékeket a szabványban előírtakkal. A korábbi vizsgálatok során azonosított kiválások és zárványok anyagösszetételét is elemezni tudjuk ezzel a módszerrel.

\subsection{Keménységmérés}

A jelenlegi kutatásban vizsgált káresetek kivizsgálásának utolsó lépése az implantátumanyag keménységvizsgálata. A metallográfiai vizsgálathoz elkészített próbatesteken HV1-es keménységmérést végeztünk (Bühler 1105 berendezéssel), a minták felületén kereszt- és hosszirányban, a minta széléről indulva $1 \mathrm{~mm}$-es lépésközzel. A keménységeredmények szintén összevethetők a szabványban előírtakkal, továbbá a teljes keresztmetszeten végzett méréssel az esetleges inhomogenitások is észrevehetők.

\section{Eredmények}

\subsection{Szemrevételezés és fraktográfia}

A szemrevételezés eredményeként jól láthatóak voltak az implantátumok felületein a kisebb-nagyobb felszíni karcolások, sérülések. Ezek feltehetően az eltávolítás során keletkeztek, és nem függenek össze a károsodással. A lemez esetében szembetűnő volt az eloxált rétegnek a kopása (2, 3. ábra).

A sztereomikroszkóppal végzett makrofraktográfiai vizsgálat eredményeként jól lehetett látni a fáradásos törés jellemzőit. A töretfelületen csontkérgi maradványok nem voltak beékelődve. A rögzítőlemez esetében a csavarmenetből kiinduló repedésvonalakat lehetett észrevenni (4. ábra). A szárak felületéből feltételezhető, hogy a törés egy hosszabb folyamat volt, a két szár nem egy időben tört el. A lemez egyik szárfelületén képlékeny alakváltozás látható, amely az anyag hosszabb ideig tartó egymáshoz ütődéséből származik, míg a másik szárrészen a fáradásos törésre jellemző repedésterjedés nem látható, sokkal inkább rideg törésre utal (5. ábra).

A protézis esetében a törésfelületen több repedést lehetett észrevenni, amelyek a felszínre futottak (6. ábra). Ebben az esetben is a fáradásos törés jellemzőit véltük felfedezni.

\subsection{Metallográfiai vizsgálat}

A lemez metallográfiai vizsgálatával megállapítottuk, hogy finomszemcsés, homogén szemcseszerkezete van, és a finom kiválások eloszlása

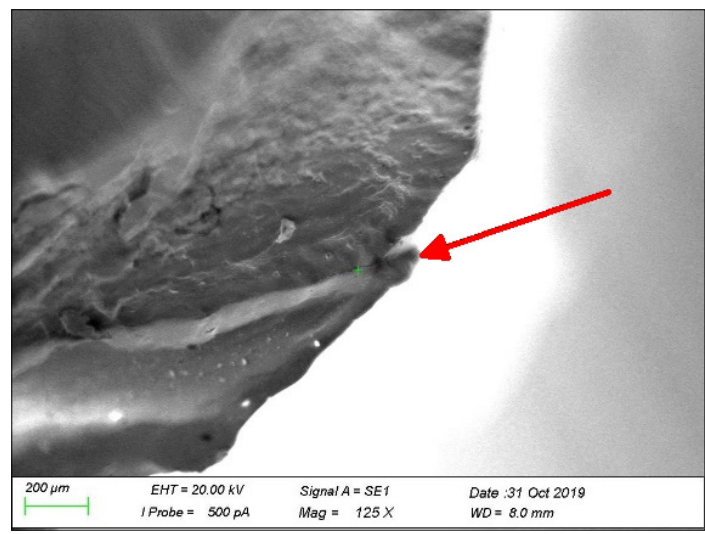

4. ábra. A csontrögzítö lemez törésfelületei pásztázó elektronmikroszkóppal készített felvételen 
egyenletesen diszperz (7. ábra). A lemezt rögzítő csavart is alávetettük metallográfiai vizsgálatnak. A szemcseszerkezet megegyezett a lemez szerkezetével.

A csípőimplantátum szemcseszerkezete dendrites volt, amely a repedések terjedésének kedvezni képes (8. ábra). Az elektronmikroszkópos felvételeken megfigyeltük, hogy a repedésterjedési vonalak a dendritágak között futottak.

Anyagösszetétel szempontjából a rögzítőlemez és a hozzá tartozó csavar Ti-Al-Nb-ötvözetből, a csípőimplantátum pedig kobalt-króm ötvözetből készült.

A keménységmérés során nem kaptunk egyik implantátum esetében sem kiugró értékeket. A lemez esetében az értékek a 300 HV1 körüli tartományba estek. A mérések átlaga 300,5 HV1 volt, amely megfelel a vonatkozó szabvány (ISO 583211) értékének ( $32 \mathrm{HRC}=300 \mathrm{HV}$ ). A lemezhez tar-

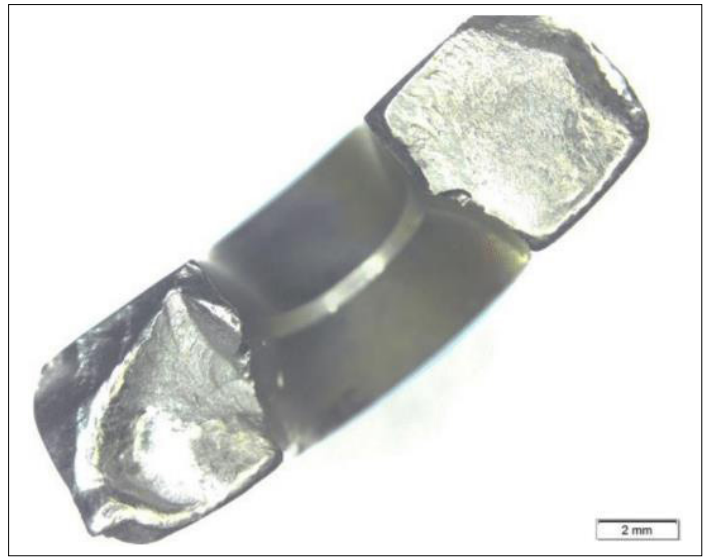

5. ábra. A csontrögzítő lemez törésfelületei sztereomikroszkóppal készített felvételen

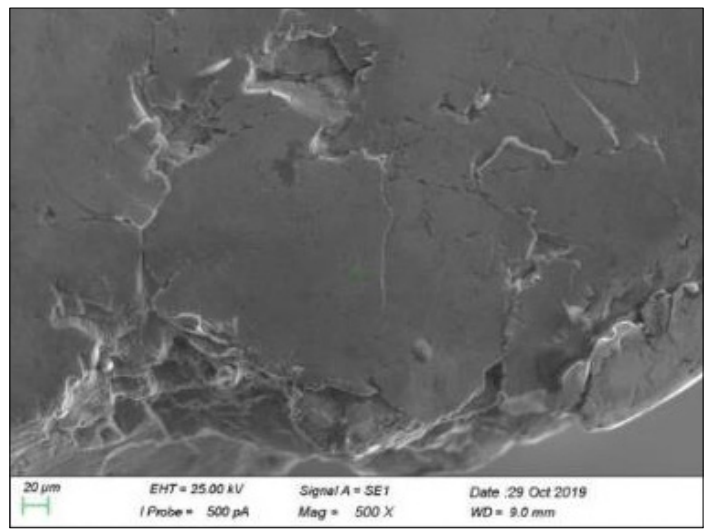

6. ábra. A protézis törésfelülete elektronmikroszkóppal (jól láthatók a felszínre futó repedések) tozó csavar keménységértékei 305,6 és 316,9 HV1 értékek között mozogtak, átlaga 309,62 HV1 volt. A csípőprotézis értékei 303,2-348,9 HV1 értékek között voltak. Átlaga 327,75 HV1 volt, amely szintén megfelelt a szabványban (ISO 5832-4) előírt értéknek (33 HRC = 311 HV).

\section{Következtetések}

A rögzítőlemez esetében a törést elindító repedések a csavarfelületről származtak. A töretfelület fraktográfiai értékeléséből arra lehet következtetni, hogy a két része nem egy időben tört el, mivel az egyik száron nagymértékü képlékeny alakváltozást lehetett megfigyelni, ami betudható a töretfelületek repedésterjedés közbeni folyamatos egymásnak ütközésének. A törést kiváltó ok lehetett egy csontdarabka által kiváltott karcolás, de akár a csavar túlzott befeszítése is. A csípőimplantátum esetében a törést kiváltó ok ismeretlen,

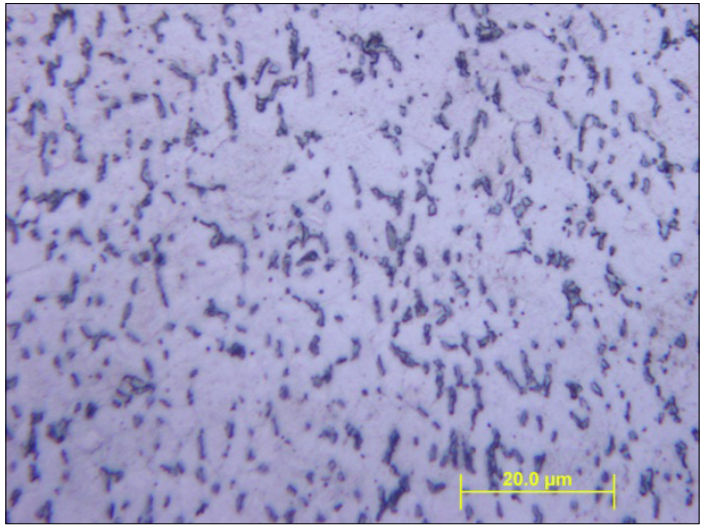

7. ábra. A csontrögzítő lemez mikroszerkezete, polírozott állapotú csiszolaton, finom, diszperz kiválásokkal

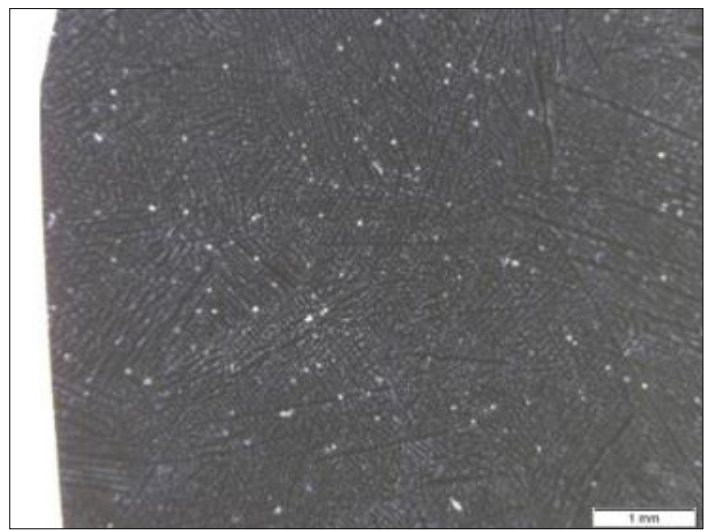

8. ábra. A csípőimplantátum szárának dendrites szerkezete 
de a fáradásos törési károsodás a legvalószínűbb. A felületen észlelt repedések a kiindulási pontjai lehettek a törésnek. A mütéti beavatkozás közben is sérülhetett a felület, amely hosszú távon, az itt végbement repedésképződés utáni fáradásos repedésterjedéssel az implantátum törését okozta.

A vizsgált eszközök anyagösszetétele és keménysége megfelelt a szabványokban előírtaknak, viszont kutatásunk olyan tényezőket tárt fel (pl. a diszperz kiválások), amelyek jelentősen növelik az implantátum anyagának szilárdságát.

\section{Szakirodalmi hivatkozások}

[1] Sargeant A. et al.: Hip implants: Paper V. Physiological effects. Materials \& Design, 27/4. (2006) 287-307.

https://doi.org/10.1016/j.matdes.2004.10.028

[2] Derar H. et al.: Recent Patents and Designs on Hip Replacement Prostheses. The Open Biomedical Engineering Journal, 9. (2015) 92-102. https://doi.org/10.2174/1874120701509010092

[3] Krettek C. et al.: Evolution of Minimally Invasive Plate Osteosynthesis (MIPO) in the femur). International Journal of the Care of the Injured, 32/3. (2001) 14-23. https://doi.org/10.1016/S0020-1383(01)00180-2

[4] Martens M. et al.: Factors in the Mechanical Failure of the Femoral Component in Total Hip Prosthesis: Report of Six Fatigue Fractures of the Femoral Stern and Results of Experimental Load- ing Tests. Acta Orthopaedica Scandinavica, 45/5. (1974) 693-710. https://doi.org/10.3109/17453677408989679

[5] Carlsson A. S., et al.: Fracture of the femoral prosthesis in total hip replacement according to charnley. Acta Orthopaedica Scandinavica, 48/6. (1977) 650-655. https://doi.org/10.3109/17453677708994812

[6] Collins D. K. et al.: Femoral stem failure in total hip replacement. Journal of Bone and Joint Surgery A, 69/8. (1977) 1033-1041.

[7] Wilson L. F. et al.: Fracture of the femoral stem of the ring TCH hip prosthesis. Journal of Bone and Joint Surgery B, 74/5. (1992) 725-728. https://doi.org/10.1302/0301-620X.74B5.1527122

[8] Lizano-Diez X. et al.: Fracture of the femoral component after a lightning strike injury: $A$ case report. Acta Orthopaedica et Traumatologica Turcica, 51/1. (2017) 84-87.

https://doi.org/10.1016/j.aott.2015.04.001

[9] Srimongkol S.: A review of mathematical modelling in total hip replacement. International Mathematical Forum, 7/52. (2012) 2561-2569.

[10] Godec M.: Material failure of an AISI $316 l$ stainless steel hip prosthesis. Materiali in Tehnologije, 45/2. (2011) 85-90.

http://mit.imt.si/izvodi/mit112/godec.pdf

[11] Collier J. P. et al.: Corrosion between the components of modular femoral hip prostheses. Journal of Bone and Joint Surgery B, 74/4. (1992) 511-517. https://doi.org/10.1302/0301-620X.74B4.1624507 